\title{
DIAMOND POTENTIAL IN BRITISH COLUMBIA, CANADA?
}

\author{
George J. Simandl ${ }^{1,2}$ \\ ${ }^{1}$ British Columbia Geological Survey; ${ }^{2}$ University of Victoria, Canada
}

\section{INTRODUCTION}

The main objective of this paper is to describe the possible significance of the reported microdiamond /diamond occurrences in British Columbia (BC) and assess BC's diamond potential, in terms of traditional "deep keel" and controversial "subduction zone" diamond stability environments. Geological diamond potential of $\mathrm{BC}$ in terms of unconventional diamond host rocks, that until recently were not believed to have a potential as a diamond host, may also warrant some reassessment.

\section{TECTONIC SETTING OF BC ALKALINE PROVINCE:}

The BC Alkaline Province is located on the western margin of North America, within Canadian Cordillera. Tectonic setting of BC can be described in terms of the North American continent, adjacent pericratonic and displaced terranes, and accreted superterranes. The Canadian Cordillera is located on the oceancontinent boundary since a supercontinent called Rodinia started to rift apart, more than $530 \mathrm{Ma}$ ago (Price and Monger, 2000). At that time Panthalassa (the ancestor of the present Pacific Ocean Basin) started to form. The subduction along the western margin of North American craton started about $390 \mathrm{Ma}$ ago and since that time a large proportion of the Pacific Ocean Lithosphere disappeared beneath North America. Cache Creek, Wrangellia and Alexander are interpreted as very far traveled terranes (Price and Monger 2000; Monger and Nokleberg, W.J., 1996). Quesnellia, Stikinia and Slide Mountain terranes are considered as ancient portions of the North American plate, but they were displaced relative to their current position at the margin of the North American Craton. Pericratonic terranes are those that formed near the craton and some of them were displaced.

\section{GEOLOGY OF THE BC ALKALINE PROVINCE}

BC's alkaline province is belt-shaped and it approximately follows the margin of the North American continent. It consists of a variety of rocks, including lamproites (McCallum, 1994); carbonatites, kimberlites, alkaline complexes, syenite gneisses (Pell, 1994) and wide variety of lamprophyres (Ijewliw, 1991). Of particular interest to the diamond exploration community are four major ultrabasic diatreme/dyke clusters. The Northern clusters (Ospika River and Kechika), central cluster (Golden) and southern cluster (Cranbrook) were previously described by Ijewliw (1991), Pell (1994) and Helmstaedt et al., (1988). The lithology of these ultramafic dykes and diatremes varies widely and includes calcalkaline and alkaline lamprophyres, possibly limburgites, olivine mellilitites, lamproites and kimberlites (Ijewliw 1991, McCallum (1994) and Pell, 1994) and rocks of basaltic affinity. A variety of basaltic and ultramafic dykes and lamprophyre rocks within the province were reported outside of these clusters, but these occurrences were neither compiled nor studied in detail.

\section{AGE OF DIATREMES AND DYKES}

Ospika pipe cuts middle Ordovician rocks $(\mathrm{Rb} / \mathrm{Sr}$ date $334 \pm 7 \mathrm{Ma}$; K/Ar $323 \pm 10 \mathrm{Ma}$ ). Diatremes of the Golden cluster cut Upper Cambrian rocks and are believed to be Late Silurian to Early Devonian in age (Mica - Rb/Sr 409 $\pm 6 \mathrm{Ma}$ and K/Ar $391 \pm 5 \mathrm{Ma})$. They lie below a Middle Devonian unconformity (Ijewliw 1991). Cross Kimberlite $\mathrm{Rb} / \mathrm{Sr}$ dates on phlogopite are 240-250 Ma (Grieve, 1982; Smith et al., 1988). Parish and Reichenbach (1991) sampled a number of diatremes including Cross, Blackfoot and Joff in the Cranbrook cluster and Jack, Mark, Mike and $\mathrm{HP}$ for $\mathrm{U}-\mathrm{Pb}$ dating. Obtained dates varied from 
2.7 Ga to $440 \mathrm{Ma}$. These ages and variations are not believed to represent ages of diatremes. The pipes contain both mantle and crustal xenoliths. The zircon xenocrysts were probably derived from a combination of sources including basement gneisses and local intrusive rocks. Some of the zircons may have been originally liberated by weathering from the western Canadian Shield, shed westward and incorporated into pericratonic terrains. The stratigraphic evidence suggests that diatremes of the Cranbrook area were emplaced during several pulses, prior to Late Devonian unconformity (Pell, 1994; Helmstaedt et al., 1988).

\section{HIGH PRESSURE METAMORPHIC ROCKS AND ALKALI BASALTS}

These two groups of rocks are not known to carry diamonds in British Columbia, however they host diamonds in several localities around the world. More importantly, they are also key supporting elements for the "ES-diamond Model". High-pressure (blue schist-and eclogitefacies) rocks, interpreted as subduction zone related, are known along the margin of Ancestral North America, from Alaska to Mexico (including $\mathrm{BC}$ ). Their isotopic ages, range from 37 to $447 \mathrm{Ma}$ (Late Cretaceous to Middle Paleozoic (Erdmer et al.1998), however, at this stage it is not clear if these dates represent peak metamorphic conditions or later cooling or re-setting. Alkali basalts contain mantle xenoliths (Fuji and Scarfe, 1982; Mitchell, 1987; Peslier, 1998), mainly spinel lherzolite and much less abundant olivine websterite, websterite, clinopyroxenite and wehrlite. Both high-pressure metamorphic rocks and alkali basalts are located west of the alkaline province. It is possible that even some of the ultrabasic diatremes within BC's alkaline province, as described earlier, may be subduction related or may have intersected the rocks that were previously in the diamond stability field.

\section{DIAMOND OCCURRENCES IN BC}

Microdiamonds were reported in samples from Jack (Lens Mountain) and Mark (Valenciennes River) diatremes (Northcote, 1983a,b). These Diatremes are part of Golden Cluster. A single microdiamond was reported from a poorly described breccia within the Xeno carbonatite complex, which is located within the Kechika area (Roberts, 2002). This locality was explored mainly for $\mathrm{REE}, \mathrm{Nb}$ and $\mathrm{Ta}$. Macrodiamonds were also reported within the Cranbrook cluster, from Bonus (Allan, 1999) and Ram 5 and 6 pipes by Consolidated Ramrod Gold Corporation, exploration predecessors of Skeena Resources Limited (Allan, 2002 and George Cross News Letter, 1994), however no microdiamonds were recovered from 143 metres of split NQ core drilled by Skeena that intersected the Ram- 6 pipe (Allan, 2002). There is little public information about the morphology of the recovered BC micro-diamonds and the inclusions that they may contain. Nitrogen content and isotopic composition of diamonds is not known, so the speculation about their origin is not constrained. Indicator mineral data is covered mainly in assessment reports of the BC Ministry of Energy and Mines and in Fipke et al. (1995). Studies of indicator minerals, in a number of ulrabasic diatremes, suggest that they originated within or near the diamond stability field as expected under the "diamondiferous mantle root model". Up to now, only the Cross pipe is officially confirmed as true kimberlite, but it is possible that Bonus and Ram 5 and 6 diatremes may turn out to be kimberlites as well. Peace River Arch area, which attracted few minor staking diamond rushes over the last few years remains active but no diamonds or microdiamonds were reported up to know.

\section{DIAMONDIFEROUS MANTLE ROOT MODEL}

The present tectonic setting of the diamond occurrences in $\mathrm{BC}$ does not match the traditional "deep keel" or " diamondiferous mantle root model" as described by Haggerty (1986), Boyd and Gurney (1986), Mitchell (1991). Classical diamond producing areas are located within stable cratons and not surprisingly, Cordillera would not be rated as highly prospective for diamonds if Clifford's Rule, as described by Janse (1994a), is strictly applied. If BC's diamond occurrences have to be explained by the "deep keel" hypothesis, then we have two possible avenues to follow. The basement rocks of similar age and nature as those that underlie the diamondiferous and potentially economic kimberlites occurrences in Alberta may extend into eastern BC. Alternatively, since the tectonic 
history of British Columbia through geological time is very complex, there is a possibility that British Columbia may have been underlayed by a "deep keel" in the past. For example, extensional tectonic regime and rifting within Rhodinia is believed to have started $750 \mathrm{Ma}$ and then again in Late Proterozoic to Early Cambrian (550-530 Ma). This activity was followed by sea floor spreading (separation of Rhodinia), initiation of proto-Pacific Ocean, by deposition of miogeosynlinal sediments and ultimately by a long lasting and evolving subduction regime. If this is correct, then 750 Ma ago the west coast of BC, was matched with the Eastern Australia (Dutch 2002) and conceivably it may have been underlain by a mantle root.

\section{SUBDUCTION ZONE DIAMOND HYPOTHESIS}

An other possible way to explain the origin of diamond occurrences in BC is in terms of "ESDiamond Model" which was originally proposed by Barron et al. (1994) and considered for British Columbia by Simandl (1998). The main attraction of this model is created by the slope of diamond / graphite stability line on PT diagram. Studies describing metamorphic and P-T-t conditions and thermal modeling as related to subducting slab incorporate variables such as angle of subduction, length and thickness of the UPH fragment, heat flow rate, convergence (subduction) and exhumation rates, shear heating and convection of subcontinental mantle (Ponco and Peacock 1995; Roselle and Engi, 2002) suggest much cooler isotherm $\left(500-600^{\circ} \mathrm{C}\right.$ at $100 \mathrm{~km}$ depth) within the subducting slab than what would be expected for the continental near the "mantle root area", where temperature may be in the $1000-1400^{\circ} \mathrm{C}$ range at depth of $100 \mathrm{~km}$. Depending on the parameters, such modeling exercises indicate that the diamond stability field could exist in subduction zone setting. Discovery of microdiamonds in ultra high pressure UPH metamorphic rocks in Dabie Shan Mountains in China (Xu et al., 1992), in ophiolites (Bai, 1993) and in variety of metamorphic rocks (garnetbiotite gneiss, dolomitic marble and garnetkyanite-phengite-quartz schist within Kokchetav massive in Northern Kazachstan (Kytayma et al., 2001) demonstrate that the diamondiferous mantle root model is not required to form diamond. The validity of this model in exploration still remains to be proven.

\section{OTHER UNCONVENTIONAL TYPES OF DIAMOND OCCURRENCES AND PLACERS}

For an excellent compilation of unconventional diamond occurrences, worldwide, see Janse (1994b). The discovery of diamonds in ophiolitic assemblages, such as those in Tibetan ophiolites described by Bai et al., (1993) may be particularly relevant to BC. Diamond placer or paleo-placer potential of British Columbia was not seriously considered either, since it is dependent on the potential sources of primary diamond deposits.

\section{DISCUSSION AND SUMMARY}

The "diamondiferous mantle root model" remains the workhorse of the diamond exploration community and it directs the flow of exploration money. However, since the discovery of the lamproite-hosted Argyle Mine, the exploration community is more open to look at "off-craton" localities especially Mobile Belts. Recent discoveries of potentially economic diamond occurrences in non-traditional geological lithologies in Ontario, unexplained alluvial diamond occurrences in the Western USA and Alaska and reported diamond occurrences in BC, near the NWT -Yukon border, and near the west coast of Alaska indicate that exploration geologists should keep an open mind. They should be ready to use paleo-tectonic data to find location of ancient diamondiferous mantle roots that may not exist anymore, but may have been intercepted by diamond transporters such as kimberlites and lamproites in the past. New models (including the controversial "ES Diamond Model") should not be discarded without careful consideration. Probably, the ideal starting point in the evaluation of the British Columbia's diamond potential would be to independently confirm all the reported diamond occurrences in BC, to eliminate any possibility of contamination (unless diamonds in higher concentrations are found). Recovered diamonds should be physically, chemically and isotopically characterized, their inclusions and related indicator minerals systematically studied and documented and interpreted to see if it is in line 
with "diamondiferous mantle root model", Argyle setting, "ES-diamond Model" or if an alternative hypothesis is required. Depending on results, the interest in diamond exploration in the province may be enhanced and exploration future exploration better focused.

\section{SELECTED BIBLIOGRAPHY}

Allan, R.J. (1999): Micro-Diamond Results from Ice

Claim Project, B.C.; Skeena Resources Ltd. News Release (August 20, 1999), 2 pages.

Allan, R.J. (2002): Diamond Exploration Corporate Up-date; Skeena Resources Limited, News Release (March 22, 2002), 1 page.

Bai, W., Robinson, P.T. and Zhou, M. (1993): Diamond-Bearing Peridotites from Tibetan Ophiolites: Implication for Subduction-Related origin of Diamonds; In: Kathryn P.E. Dunne and Brian Grant editors, Mid-Continental Diamonds; GAC-MAC Symposium Volume, Edmonton, Alberta; Geological Association of Canada, pages 77-82.

Barron, L.M., Lishmund, S.R., Oakes, G.M. and Barron, B.J. (1994): Subduction Diamonds in New South Wales: Implications for Exploration in Eastern Australia; Geological Survey of New South Wales, Quarterly Notes, Vol. 94, pages 1-23.

Boyd, F.R. and Gurney, J.J. (1986): Diamonds and the African Lithosphere; Science, Vol. 232 , pages $472-477$.

George Cross News Letter (1994): Consolidated Ramrod Gold Corporation; BC. Diamonds Discovered, No.225 (November 24, 1994)

Dummett, H., Fipke, C. and Blusson, S.L. (1985): Diamondiferous Diatremes of Eastern British Columbia; Canadian Institute of Mining and Metallurgy Bulletin, Vol. 78, pages $56-58$.

Dutch, S. (2002): History of Global Plate Motions; www.uwgb.edu/dutchs/platetec/plhist94. htm.
Erdmer, P., Ghent, E. D., Archibald, D.A. and Stout,

M.Z. (1998): Paleozoic and Mesozoic High Pressure Metamorphism at the Margin of Ancestral North America in Central Yukon; Geological Society of America Bulletin, Vol.110, no.5, pages 615-629.

Fipke, C.E., Gurney, J.J. and Moore, K.O. (1995): Diamond Exploration Techniques Emphasizing Indicator Mineral Geochemistry and Canadian Examples; Geological Survey of Canada, Bulletin 423, 85 pages.

Fuji, T. and Scarfe, C. M. (1982): Petrology of Ultramafic Nodules from West Kettle River, near Kelowna, Southern British Columbia; Contributions to Mineralogy and Petrology, Vol.80, pages 297-306.

Gabrielse, H., Monger, J.W.R., Wheeler, J.O. and Yorath, C.J. (1991): Part A., Morphogeological Belts, Tectonic Assemblages and Terranes; In: Chapter 2 of Geology of the Cordilleran Orogen in Canada, H. Gabrielse and C.J. Yorath editors; Geological Survey of Canada, No. 4, pages 15-28.

Gehrels, G.E. and Ross, G.M. (1998): Detrial Zircon

Geochronology of Neoproterozoic to Permian Miogeoclinal Strata in British Columbia and Alberta: Canadian Journal of Earth Sciences, Vol. 35, pages 13801402.

Grieve, D.A. (1982): Diatreme Breccias in the Southern Rocky Mountains. in: Geological Fieldwork 1980, British Columbia Ministry of Energy, Mines and Petroleum Resources, Paper 1981-1, pages 96-103.

Haggerty, S. E. (1986): Diamond Genesis in a Multiply Constrained Model: Nature, Vol. 320 , pages $34-38$.

Helmstaedt, H.H., Mott, J.A., Hall, D.C., Schulze, 
D.J. and Dixon, J.M. (1988): Stratigraphic and Structural Setting of Intrusive Breccia Diatremes in the White River-Bull River Area, Southeastern British Columbia. British Columbia Ministry of Energy, Mines and Petroleum Resources, Geological Fieldwork 1987, Paper 1988-1, pages 363-368

Ijewliw, O.J. (1991): Petrology of the Golden Cluster

Lamprophyres, Southeastern British Columbia, Canada. M.Sc. Thesis. Queen's University, Kingston, Ontario, 270 pages.

Janse, A.J.A. (1994a): Is Clifford's Rule Still Valid?;

In: Henry O.A. Meyer and Othon $\mathrm{H}$. Leonardos Editors, Kimberlites, Related Rocks and Mantle Xenoliths, Proceedings of the $5^{\text {th }}$ International Kimberlite Conference, Araxa, Volume 2; Companhia de Pesquisa de Recursos Minerais - CPRM, Special Publication 1/A Jan 94, Brasilia, pages 215-235.

Janse, A.J.A. (1994b): Review of Supposedly Non-

Kimberlitic and Non-Lamproitic Diamond Host Rocks; In: Henry O.A. Meyer and Othon H. Leonardos Editors, Kimberlites, Related Rocks and Mantle Xenoliths, Proceedings of the $5^{\text {th }}$ International Kimberlite Conference, Araxa, Volume 2; Companhia de Pesquisa de Recursos Minerais - CPRM, Special Publication 1/B Jan 94, Brasilia, pages 144-159.

Katayama, I., Maruyama, S., Parkinson, C.D., Terada, K. and Sano, Y. (2001): Ion Micrprobe U-Pb Zircon Geochronology of Peak and Retrograde Stages of UltrahighPressure Metamorphic Rocks from the Kokchetav Massif, Northern Kazachstan; Earth and Plaetary Science Letters, Vol. 188, pages $185-196$.

McCallum, M.E. (1994): Lamproitic(?) diatremes in the Golden Area of the Rocky Mountain Fold and Thrust Belt, British Columbia, Canada. In: Henry O.A. Meyer and Othon H. Leonardos Editors, Kimberlites,
Related Rocks and Mantle Xenoliths, Proceedings of the $5^{\text {th }}$ International Kimberlite Conference, Araxa, Volume1; Companhia de Pesquisa de Recursos Minerais - CPRM, Special Publication 1/A Jan 94, Brasilia, pages 195-209.

Mitchell, R.H. (1987): Mantle-Derived Xenoliths in

Canada; In: Peter, H. Nixon, editor; Mantle Xenoliths, John Wiley \& Sons Ltd., pages 33-40.

Mitchell, R.H. (1991): Kimberlites and Lamproites: Primary Sources of Diamonds; Geoscience Canada, Vol. 18, pages 1-16.

Monger, J.W.H. and Nokleberg, W.J. (1996): Evolution of the Northern North American Cordillera; Generation, Fragmentation, Displacement and Accretion of successive North American Plate-Margin Arcs; In: Coyner, A.R. and Fahey, P.L., editors; Geology and Ore Deposits of the American Cordillera, Geological Society of Nevada Symposium Proceedings, Reno/Sparks, Nevada, April 1995, pages 1133-1152.

Northcote, K.E. (1983a): Report on Mark Property, Pangman Peek (82N/15W); British Columbia Ministry of Energy and Mines Mines and Petroleum Resources, Assessment Report 13596, 32 pages.

Northcote, K.E. (1983b): Report on Jack Claims Lens Mountain (82N/14E); British Columbia Ministry of Energy, Mines and Petroleum Resources, Assessment Report 13597, 26 pages.

Parish, R.R. and Reihenbach, J. (1991): Age of Xenocrystic Zircons from diatremes of Western Canada; Canadian Journal of Earth Science, Vol.28, pp.1159-1238.

Pell, J. (1994): Carbonatites, Nepheline Syenites, Kimberlites and Related Rocks in British Columbia; British Columbia Ministry of Energy and Mines, Bulle tin 88, 136 pages.

Peslier, H.A. (1998): Pétrologie et Géochimie 
Isotopique de Xénolites Mantelliques de

la Cordillère Canadienne; Université de Montréal, Ph.D. Thesis, 184 pages.

Ponco, S.C. and Peacock, S.M. (1995): Thermal

Modeling of the Southern Alaska

Subduction Zone: Insight into the

Petrology of the Subducting Slab and

Overlying Mantle Wedge; Journal of

Geophysical Research, Vol.100, No. B11, pages 22,117-22,118.

Price, R.A. and Monger, J. W. H. (2000): A Transect

of the Southern Canadian Cordiellera from Calgary to Vancouver; A Fieldtrip Guidebook, Geological Association of

Canada - Cordilleran Section, 164 pages.

Roberts, W.J. (2002): Diamond Discovery at Xeno;

News Release Wednesday, March 13, 2002, 1 page.

Roselle, G.T. and Engi, M. (2002): Ultra High Pressure (UPH) Terrains: Lessons from Thermal Modeling; American Journal of Science, Vol. 302, pages 410-441.

Simandl, G.J. (1998): Gemstones in Volcanic Arc

Environments; In: Metallogeny of Volcanic Arcs, British Columbia Ministry of Energy and Mines, Short Course Notes; Open File 1998-5, Section B, pages J1-J12.

Smith, C.B., Colgan, E.A., Hawthorne, J.B. and Hutchinson G. (1998): Emplacement Age of the Cross Kimberlite, Southeastern British Columbia, by $\mathrm{Rb}-\mathrm{Sr}$ Phlogopite Method; Canadian Journal of Earth Sciences, Vol.25, pages 790-792.

Xu, S., Okay, A.I., Ji, S. Sengor, A.M.C., Su, W., Liu, Y., and Jiang, L. (1992): Diamond from Dabie Shan Metamorphic Rocks and its Implication for Tectonic Setting: Science, Vol. 256, pages 80-82.

Contact: George J. Simandl, British Columbia Ministry of Energy and Mines, PO Box 9320 Stn Prov Govt, Victoria, BC, Canada,V8W 9N3. 